\title{
Factors Influencing Examination Cheating Behaviors by Consumers of Post- Primary Education in Enugu, Nigeria
}

\author{
Ifediora Raluchukwu Ifeoma \\ Doctoral Candidate \\ Department of Educational Administration and Planning, \\ Ebonyi State University,Abakaliki ,Nigeria \\ E-mail: chuka.ifediora@unn.edu.ng \\ Ifediora Chuka Uzoma Ph.D \\ Department of Marketing \\ University of Nigeria, Nigeria \\ E-mail: chuka.Ifediora@unn.edu.ng \\ Ugwuanyi Chidera Christian \\ Department of Marketing \\ University of Nigeria, Nigeria \\ E-mail: chidera.ugwuanyi@unn.edu.ng
}

\begin{abstract}
This study evaluates the factors influencing examination cheating behaviors by consumers of post-primary education in Enugu, Nigeria. The study objectives were to; determine whether the gender of consumers of post-primary education has a significant influence on the incidence of examination cheating behaviors in post-primary schools in Enugu, Nigeria, and; ascertain the significant causes of examination cheating behaviors among consumers of post-primary education in Enugu, Nigeria. The study adopted a descriptive research design. Examiners of external and internal examinations in post-primary schools in Enugu, Nigeria were the target population for the study. A sample size of 246 was chosen from this population. A structured questionnaire was the instrument for data collection, while the t-test was used for the hypotheses tests at $5 \%$ level of significance. The hypotheses tests revealed that; gender of consumers of post-primary education has no significant influence on the incidence of examination cheating behaviours in post-primary primary schools in Enugu, Nigeria and; inadequate preparation, environmental influence and poor infrastructure in schools are the significant causes of examination cheating behaviors among consumers of post-primary education in Enugu, Nigeria. Following the findings, the study concludes that though male consumers of educational services have a higher tendency of engaging in examination cheating behaviors than female consumers of educational services in Enugu, Nigeria. This influence of gender has been shown to be insignificant. Also, examination cheating behaviors among consumers of educational services in Enugu, Nigeria are caused by a combination of personal attributes of the consumers and group/societal influences.
\end{abstract}

Keywords: Consumers, Gender, Cheating Behavior, Examination, Post-primary School.

\section{Introduction}

Examination cheating behavior is an unauthorized action, inaction, activity, behavior or practice that is associated with the preparation, conduct and processing of examination and other forms of assessment and carried out by any person involved in preparing for, giving, taking and processing the examination at any level (Joshua, 2008a). Examination cheating behavior often referred to as examination malpractice, is an illegal act committed by a student, teacher, invigilator, supervisor, school administrator, parent or any other public officer either in government ministry/parastatal or examination body before, during and after an examination to obtain or award underserved marks or grades.

Thus, perpetrators of examination cheating behavior span across students, teachers, school administrators, parents, government, society, among others. However, this study concentrates on the examination cheating behavior of students who are the primary 
consumers of educational services in Nigeria. A consumer refers to the user of a good or service (Craven \& Piercy, 2013; Kotler $\&$ Armstrong, 20I4; Kotler \& Keller, 2012). The consumers' inactions and actions determine the survival of service providers (Berger, Bolton, Bowman, Briggs, Kumar, Parasuraman \& Terry, 2002). Thus for educational service providers, the cheating behavior of students has implications for educational development in any nation.

Examination cheating behavior is an academic disease that has affected and infected many members of the institutional team or many stakeholders in the education industry and poses a severe threat to education standards and credibility of school certificates awarded in Nigeria and other countries. Education cheating behavior is academic fraud and a form of corruption which derives from the corrupt nature of the social system operating in Nigeria currently (Joshua, 2008b). According to Onyechere (2003) in Jega (2006), examination malpractice has become a national disaster in Nigeria and every disaster brings an emergency situation that requires all hands on deck. A summary of the West African Examination Council (WAEC) annual statistical report of examination malpractice for the WAEC/ SSCE post-primary exit examination between the year 2000 and 2010 shows that 78I,09I (8.25\%) of 9,465,978 candidates who sat for WASSCE were either withheld or canceled during the period as a result of examination malpractice. The records further show that the Examination Malpractice Index (EMI) had remained persistently high ranging between 5.47 and 12.87 during the period surveyed. The implication is that out of every IOO students who wrote WAEC between the period of 2000 and 2010 in Nigeria, not less than 8 of them exhibited examination cheating behavior (WAEC, 2010).

Many strategies have been advanced in the literature and devised by the government to curb this menace of examination cheating behavior. However, as a monster, it is still thriving and growing in the school system. The Federal Government of Nigeria Promulgated Decree 33 of 1999 which stipulates many strict penalties for various offenses associated with the conduct of examinations (FRN, 1999). The various school authorities, colleges, academic boards, university senates among others, have enacted similar laws to fight this monster called examination malpractice, yet the monster seems to be thriving and looming majestically in school systems. For instance, Obo (2008) shows how states in Nigeria have been competing in taking top positions in the ranking of their examination malpractice indices and how this index for the country increased from 4.5 in 1999 to 16.9 in 2004 (an increase of 276\%). There is, therefore, a severe need to fight this menace from different fronts, including the perspective of finding out the if gender composition of schools (i.e., whether male or female) has any influence on the incidence of examination cheating behaviors among students who are the primary consumers of post-primary education in Nigeria.

Many factors influence the phenomenon of examination malpractice. According to Ivowi (I997), lack of confidence as a result of inadequate preparation, peer influence, societal influence, parental support and inadequate facilities in schools are some of the factors responsible for examination malpractices. Nwandiani (2005), Okafor (2006), Ayua (2006), Azare (2006), Aminu (2006) and Badmus (2006), identify school programs, teaching environment, the teacher, the student, over value of certificates, decadence in the Nigerian society and parental support as some factors responsible for examination cheating behavior in the Nigerian educational system.

Gender influence on examination cheating behaviors in schools has also been of interest to many researchers (e.g., Bruno \& Obidigbo, 2012; Cornelius-Ukpepi, Ndifon \& Enukoha 2012; Whitley,200I). Athanason and Olasehinde (2002) reviewed several kinds of literature relating to the influence of gender on academic cheating or dishonesty and discovered that there is a gender difference. The Minnesota State University (2006) reports that out of the four studies that included gender as a possible explanatory variable for cheating, three studies found that males were more likely to cheat while one study found no significant correlation of gender and academic dishonesty. There is, therefore, the need to find out the underlying factors that contribute to the incidence of examination cheating behaviors among students in post-primary schools in Enugu, Nigeria, most especially the influence of gender on these cheating behaviors.

\section{I.I Statement of the Problem}

The consumers' actions and inactions determine the survival of service providers (Berger et al., 2002). Thus for educational service providers, the cheating behavior of students has implications for educational development in any nation. In this regard, the persistent occurrence of examination cheating behaviors is a major concern for educational administrators, managers and marketers (Cromwell, 2000; Jega, 2006). Despite the high value placed on examinations by the Nigerian National Policy on Education (FGN, 2004), it seems that the issue of examination cheating behaviors has not been adequately tackled in Nigeria (Adeyemi, 2010). The non-solution of the problem of examination cheating behaviors poses a grave threat to education standards and credibility of school certificate in Nigeria. For instance, Olagboye(2004) laments that the situation appears so sorry that many Nigerians and interested stakeholders including employers of labor have almost lost confidence in the value of examinations and their results. Thus, there is an urgent need to find a lasting solution to the menace of examination malpractice, as its persistent occurrence has enormous consequences on the credibility of the schools, administrators and teachers, the quality of teachers and students alike, as well as the moral characters and employability of the certificate holders and indeed the value system in the society in general. 
As mentioned earlier various views (e.g., Jega, 2006; Murdock, Hale \& Webber, 2001; Olatoye, 2004; Whitley \& KeithSpiegel, 2002) have been expressed on the incidence of examination cheating behaviors in schools. However, there is yet no research evidence on the influence of gender as well as other underlying factors on the occurrence of cheating behaviors among students in examinations in post-primary schools in Enugu, Nigeria. To avoid speculation, there is need to establish empirical evidence on the influence of gender and other underlying factors on the incidence of examination cheating behaviors among students in post-primary schools in Enugu, Nigeria as we plan to do in this study. Hence the need for this study, which is on factors influencing examination cheating behaviors by consumers of post-primary education in Enugu, Nigeria.

\section{I.2 Objectives of the Study}

This study seeks to assess the factors influencing examination cheating behavior by consumers of post-primary education in Enugu, Nigeria. The sub-objectives include:

- To determine whether the gender of consumers of post-primary education has a significant influence on the incidence of examination cheating behaviors in post-primary schools in Enugu, Nigeria.

- To ascertain the significant causes of examination cheating behaviors among consumers of post-primary education in Enugu, Nigeria.

\section{I.3 Research Hypotheses}

The following hypotheses were formulated in the null form to guide the study.

Hor: Gender of consumers of post-primary education has no significant influence on the incidence of examination cheating behaviors in post-primary schools in Enugu, Nigeria.

Ho2: Inadequate preparation, environmental influence and poor infrastructure in schools are not the significant causes of examination cheating behaviors among consumers of post-primary education in Enugu, Nigeria.

\section{I.4 Justification for the Study}

The researchers cannot pinpoint any previous research that sought to ascertain the influence of gender as well as the significant causes of examination cheating behaviors among consumers of post-primary education in Enugu, Nigeria. It is envisaged that this study will add to the literature and also generate interest among various stakeholders for additional research on the cheating behaviors of consumers of educational services to minimize and possibly eliminate the adverse effects of such behaviors on educational development and societal well-being.

\section{Literature Review}

\section{I. Nature and Causes of Examination Cheating Behaviors}

Notwithstanding the importance of examinations in the educational system of a State, the instances of cheating behaviors during examinations have been identified (Cromwell, 2000). These cheating behaviors include misrepresentation of identity or impersonation, theft of other students' works, tampering with the works of others, bringing prepared answers to examination halls, wrong use of academic resources, fabrication of results and showing disregard to academic regulations (Gross, 2003). These vices are seen as academic misbehavior capable of truncating an educational system (Glasner, 2002; Ogunwuyi, 2005). They are also viewed by researchers (Omotosho, 1992; Hurwitz \& Hurwitz, 2004) as dishonesty in examinations perpetrated by a person or a group of persons. Kleiner (1999) asserts that students' definitions of what constitutes cheating are varied and often lax. In a study of 500 middle and high school students, the Center for Academic Integrity (2005) note that only one-third of the students view working with other students on assignments as cheating and just half of the students thought it wrong for parents to do their homework. Murdock et al. (200I) carried out a study on American high school students and found that half of them do not believe cheating was always wrong and nearly all cheaters said that they had never been caught. In line with these assertions, it can be deduced that most students view working together in assignments as cheating.

Furthermore, Whitley and Keith-Spiegel (2002) in the review of the literature on college students report that academic dishonesty such as cheating and plagiarism was higher among students who feel pressured to succeed and who claim a history of such dishonesty in the past. Moreover, persons who engage in academic dishonesty have moderate expectations for success, anticipate high rewards for their success, and are competitive about obtaining grades (Whitley \& Keith-Spiegel, 2002).

Bowers (1984) reports that the highest rate of academic dishonesty takes place in homework and laboratory assignment (unsupervised assignments). These unsupervised assignments may be given to students to be completed by group efforts. Ravenscroft and Buckless (1992) opine that take-home tests which are unsupervised provide an opportunity for low performing students to cheat on high-performing students.

Also, Bowers (I963) as cited in Newberger (2003) surveyed 5,000 college students, II\% of whom admitted to collaborating with other students on work that was assigned to be done individually. McCabe and Trevino (I993) replicated Bower's study in some of the same colleges and found $49 \%$ admitting to the same kind of forbidden collaboration. The results 
of these two studies imply that collaboration in assignments which is supposed to be done individually is cheating and this has also been the case among Nigerian students (Onwuamanam, 2005).

In essence, students' cheating behaviors are influenced by many factors. According to Ivowi (1997), lack of confidence as a result of inadequate preparation, peer influence, societal influence, parental support and inadequate facilities in schools are some of the factors responsible for examination malpractices. Writing in the same vein, Badmus (2006), Nwandiani (2005), Okafor (2006), Ayua (2006), Azare (2006) and Aminu (2006) identify school programmes, teaching environment, the teacher, the student, over value of certificates, decadence in the Nigerian society and parental support as some factors responsible for examination malpractice in the Nigerian educational system.

\subsection{Gender Influence on Examination Cheating Behavior}

Gender refers to sex which means male and female. Differences between males and females in either behavior or mental processes are referred to as gender differences. It has often been suggested that such differences are minimal which bolsters the argument that the two sexes are equal (Hyde \& Linn, 1988).

Research has addressed some of the correlates of cheating and has highlighted several types of factors that are associated with students' cheating behaviors: demographics and school-related/academic concerns. The strongest and most commonly reported demographic correlate of cheating is gender( McCabe \& Trevino, I999; Tang \& Zuo, 1997).

There are, additionally, differences in the factors that predict cheating for male and female students. Women are more likely to cheat based on moral beliefs and men are more driven to cheat on their own and their friends' past cheating behaviors (Tibbetts, 1997). This suggests that female cheating is linked to internal control while for males, cheating behaviors is an external control issue.

However, there has been no consensus on the findings regarding gender influence on examination malpractice. Black (1962) as cited by Nsekpong (1986) asserts that there is no significant difference between males and females concerning their level of cheating. On the contrary, Hill (1972) argues that there is a significant difference between men and women regarding their attitude toward cheating. Also, Denga (1983) observes that more males engage in cheating behavior at any given point in time than females. In contrast to the above view, Anderson (1968) as cited by Hill (1972) reports that females cheat more than males, arguing that girls tend to cheat more frequently in some subjects like mathematics while boys cheat more frequently in the vocabulary test. In contrast, Whitley(200I) observes that though women have more negative feelings regarding academic dishonesty compared to men, yet women are about as likely to cheat as men. Athanasou and Olasehinde (2002) reviewed several kinds of literature relating to the influence of gender on academic cheating or dishonesty and found that there is gender difference and that women are less likely to cheat than their male counterpart.

Cornelius-Ukpepi et al. (2012) also note that perception of examination malpractice does not differ by gender. This implies that the perception of what examination malpractice means does not depend on whether the individual is a male or female. This finding lends credence to the view of Black (1962) as cited by Nsekpong (1986) who affirms that there is no significant difference between male and female concerning their level of cheating. The finding also is in agreement with the finding of Vitro (1992) who asserts that there is no significant difference in the cheating behavior of boys and girls.

Good et al. (I999) note that there may be the difference in the perception of cheating between males and females. Accordingly, the Minnesota State University (2006), reports that out of the four studies that included gender as a possible explanatory variable for cheating, three studies found that males were more likely to cheat while one study found no significant correlation of gender and academic dishonesty.

\subsection{Theoretical Framework}

There are some psychological theories on how educational administrators, managers and marketers could make sense of rationales for education services consumers' behaviors. Some of these theories include social cognitive theory (Bandura, I99I Iab), deterrence theory (Gibbs, 1975) theory of crime (Gottfredson \& Hurschi, 1990). The social cognitive theory Bandura(I99Iab) is relevant to the present research, as it seeks to explain the factors that could influence the cheating behaviors of students who represent the particular segment of educational services consumers under study. The social cognitive theory has been known to be useful for analyzing a student's moral development and thought making process. 
The figure below depicts the model.

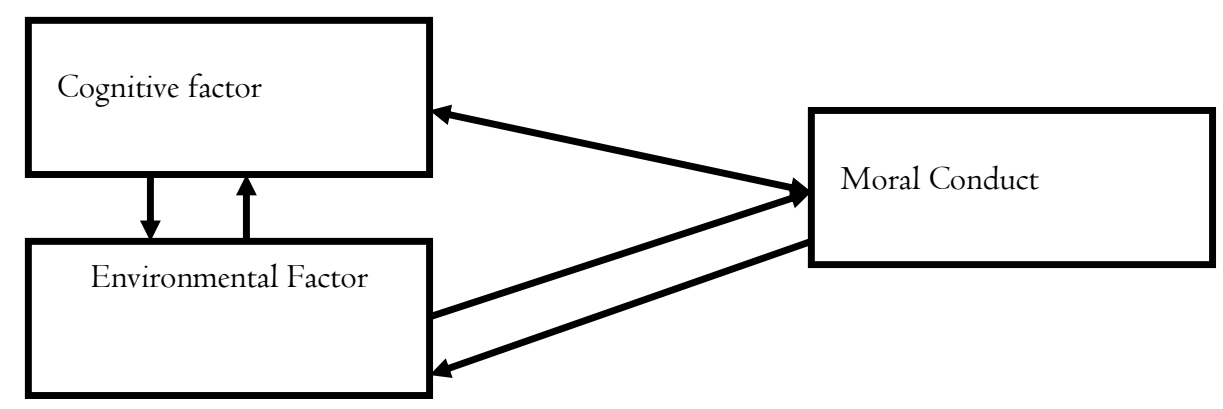

Figure I: Social Cognitive Theory

Source: Bandura, A. (I99Ia). Social Cognitive Theory of Self-Regulation. Organizational Behaviour and

Human Decision Processes, 50, 248-287.

Bandura(I99Ia) analyzed complex concepts relating to students moral actions in a three-part bi-directional model. According to the theory, moral behavior (e.g., honesty/dishonesty) is shaped by cognitive and environmental factors. Cognitive aspect according to Bandura( I99 Ib) includes intellectual and moral developmental level, reaction to situations and commitment to social norms.

According to Bandura(I99Ib), environmental variables, in this case, include a commitment to social norms, code of conduct and modeling by others. By social norms, Bandura (I99Ib) implies the perceived acceptable behavior. These norms influence what people feel they should or should not be doing. Codes of conduct also affect behavior by providing a better understanding of social norms and expectations. Finally, modeling provides people with visual clues regarding what is or is not acceptable behavior. This theory, therefore, suggests that students' behaviors could be positively impacted through the formidable code of conducts, creating a friendly learning environment and working to develop desirable social norms that are congruent with appropriate character development. According to the theory, social norms and students' commitment to them play a part in determining academic behavior.

Environments and social systems influence human behavior through psychological mechanisms of the self-system hence, social cognitive theory posits that factors such as economic conditions, socio-economic status and educational and formal structures do not affect human behavior directly instead they affect it to the degree that they influence people's aspirations, selfefficacy beliefs, personal standards emotional states and other self-regulatory influences (Bandura, I99Ia\&b).

\subsection{Empirical Reviews}

Bruno and Obidigbo (2012) carried out a study among students in the Faculties of Education and Social Sciences of Nnamdi Azikiwe University Awka, Nigeria. The second and third-year students of these two faculties were randomly selected for the study. In all, there were 200 students comprising of 100 males and 100 female. One hundred of the students came from regular programmes of the university, while the remaining 100 participants came from the Continued Education Programme (CEP) of the school. In all, there were 50 regular male students and 50 male CEP students as well as 50 regular female students and 50 CEP students. Bruno and Obidigbo (2012) found out that gender is a significant factor in examination malpractice. Bruno and Obidigbo (2012) discovered that more females than males perceive exam malpractice negatively. Compared to females, males are more aggressive and they see cheating in examinations as one of the avenues of showing their stuff (Obidigbo, 20I I).

Athanason and Olasehinde (2002) went ahead to analyze the results of reviewed literature and found that the overall proportions of female students cheating varied from a low of 0.05 to a high of 0.99 (median $=0.56$ ) and for men, the proportion varied from 0.16 to $0.9 \mathrm{I}$ (median $=0.6 \mathrm{I}$ ). There was no significant difference in the average proportions reported for males and females. On the whole, accumulating the findings, some studies that reported both proportions and the actual number of males and females involved showed that $21 \%$ of females and $26 \%$ of males had cheated. This, therefore, implies that males are more likely to cheat in examinations than females (Bruno \& Obidigbo, 20I2).

In a study carried out to examine students' perceptions of the predisposing factors towards examination malpractice among students in Lagos Universities, Badejo and Gandonu (2010) discovered that there is no significant gender difference in students' perceptions of the predisposing factors towards examination malpractice in Lagos Universities. This result implies that examination malpractice is not a function of gender; instead, both male and female students have the tendency to be involved in examination malpractice ( Badejo \& Gandonu, 2010). This finding agrees with that of Olatoye (2002) whose study reveals that examination malpractice is a general phenomenon among male and female students. 
Ossai (201 I) investigated the relationship existing between examination anxiety and students' attitude towards examination malpractices in tertiary institutions in Delta State, Nigeria. The population of the study consisted of 2,000 first year regular students in eight tertiary invitations in Delta State, Nigeria. Ossai (20II) found out that there is a significant positive relationship between examination anxiety and students' attitude towards examination malpractice in tertiary institutions in Delta State, Nigeria; and that gender does not significantly moderate this relationship. This result implies that students who manifest high examination anxiety levels are more likely to be positively disposed towards engaging in examination malpractices irrespective of their gender. The contradictory findings of various researchers seem to suggest that gender may have an influence on students' cheating behavior or may not depending on the situation the students find themselves.

\subsection{Gaps in Literature}

Several types of research have been undertaken on the incidence of examination cheating behaviors in schools (e.g. Jega, 2006; ,Murdock, Hale and Webber, 200I; Olatoye, 2004; Whitley and Keith-Spiegel, 2002) as well as on the influence of gender on students' cheating behaviours (e.g. Athanason and Olasehinde, 2002; Bruno and Obidigbo, 2012; Cornelius-Ukpepi, Ndifon and Enukoha, 20I2; Whitley,200I). However, there is yet no research evidence on the influence of gender as well as other underlying factors on the occurrence of cheating behaviors among students in examinations in post-primary schools in Enugu, Nigeria. This apparent gaps in the literature thus necessitate this study.

\section{Methodology}

The descriptive research design was adopted for the study. Survey research tools were mainly used. For this study, the target population was examiners of external and internal examinations in post-primary schools in Enugu, Nigeria. The examiners are considered knowledgeable on the topic under investigation. A sample size of 246 was chosen from this population. Convenience sampling technique was adopted for the study. The respondents were chosen according to their readiness and willingness to participate in the study. The respondents were made up of examiners of internal and external examinations in the selected postprimary schools. The post-primary schools were chosen purposively to ensure adequate representation of all categories of schools in the study. A structured questionnaire was used to collect data for the study (see Appendix I). A t-test was used to test the formulated hypotheses.

\section{Analyses, Results and Discussions}

A total of 246 ( Two hundred and forty-six) copies of the questionnaire were distributed amongst the respondents. 232 copies were returned and valid, while I4 copies were not returned. This gives a returns rate of $94.31 \%$. Only the 232 returned copies of the questionnaire were used for the analysis. The demographic data of the respondents, as well as the responses to the questions in the questionnaire, are presented in Appendix II. A 5-point Likert measurement scale was employed to extract the data used in testing the hypotheses formulated for this study. The respondents indicated the extent of their agreement or disagreement with the statements in the questionnaire. Options included strongly agree (SA), agree (A), undecided (U), disagree (D) and strongly disagree (SD). A 5\% level of significance was assumed for both hypotheses tests.

\section{I. Test of Hypothesis One}

Hor: Gender of consumers of post-primary education has no significant influence on the incidence of examination cheating behaviors in post-primary schools in Enugu, Nigeria.

$\mathrm{H}_{\mathrm{a}} \mathrm{l}$ : Gender of consumers of post-primary education has a significant influence on the incidence of examination cheating behaviors in post-primary schools in Enugu, Nigeria.

To test hypothesis one, responses to questions 15 and 18 as contained in the questionnaire were used.

Tables I, 2 and 3 contain the descriptive statistics, correlations and t-test for the questions used to test the hypothesis.

Table I:

Paired Samples Statistics

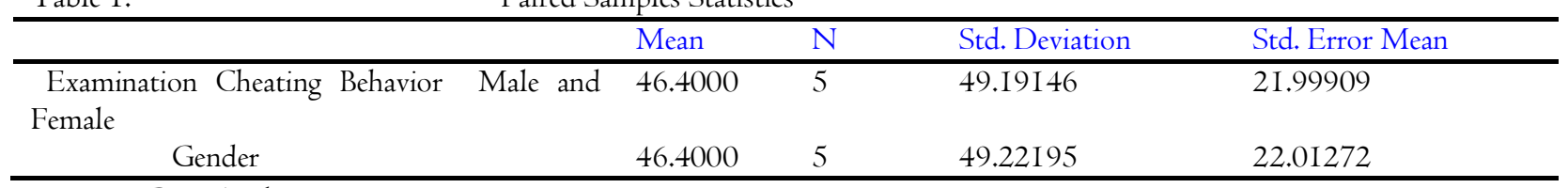

Source: Data Analysis

Table 2:

Paired Samples Correlations

\begin{tabular}{lllll}
\hline & & N & Correlation & Sig \\
\hline Pair I & $\begin{array}{l}\text { Examination Cheating Behavior Male and Female } \\
\text { Gender }\end{array}$ & 5 & .997 & .000 \\
\hline Source & & & \\
\hline
\end{tabular}

Source: Data Analysis 
Table 3:

Paired Samples Test

\begin{tabular}{|c|c|c|c|c|c|c|c|c|}
\hline & \multicolumn{5}{|c|}{ Paired Differences } & \multirow{3}{*}{$\mathrm{T}$} & \multirow{3}{*}{ Df } & \multirow{3}{*}{$\begin{array}{l}\text { Sig. (2- } \\
\text { tailed) }\end{array}$} \\
\hline & \multirow[t]{2}{*}{ Mean } & \multirow[t]{2}{*}{$\begin{array}{l}\text { Std. } \\
\text { Deviation }\end{array}$} & \multirow[t]{2}{*}{$\begin{array}{l}\text { Std. Error } \\
\text { Mean }\end{array}$} & $\begin{array}{l}95 \% \\
\text { Interval } \\
\text { Difference }\end{array}$ & $\begin{array}{l}\text { Confidence } \\
\text { of the }\end{array}$ & & & \\
\hline & & & & Lower & Upper & & & \\
\hline $\begin{array}{l}\text { Examination Cheating Behavior } \\
\text { (Male and Female) } \\
\text { Gender Composition. }\end{array}$ & .00000 & 3.93700 & 1.76068 & -4.88844 & 4.88844 & .002 & 4 & 1.000 \\
\hline
\end{tabular}

As shown in table 3 , the t-test resulted in a t-value of 0.002 and $\mathrm{P}-$ value of 1.000 which is more than 0.05 . Following this, therefore, the null hypothesis which states that the gender of consumers of post-primary education has no significant influence on the incidence of examination cheating behaviors in post-primary schools in Enugu, Nigeria. ( $t_{c a l}=$ $0.002, \mathrm{P}=1.000>0.05)$ is accepted.

This finding agrees with the view of Black (1962) as cited by Nsekpong (1986) who affirms that there is no significant difference between males and females concerning their level of cheating. The finding is also in agreement with the findings of Vitro (1992) who asserts that there is no significant difference in the cheating behavior of boys and girls. In line with this finding, Cornelius-Ukpepi and Emukoha (20I2) also found out that perception of examination cheating behaviors does not differ by gender. This present finding contrasts with the findings of Bruno and Obidigbo (20I2) and Obidigbo (20II) which assert that gender is a significant factor in examination cheating behaviors. Our findings imply that though the responses indicate a higher level of occurrence of examination cheating behaviors among males than in females, this gender influence cannot be said to be significant.

\subsection{Test of Hypothesis Two}

Ho2: Inadequate preparation, environmental influence and poor infrastructure in schools are not the significant causes of examination cheating behaviors among consumers of post-primary education in Enugu, Nigeria.

$\mathrm{H}_{\mathrm{a} 2}$ : Inadequate preparation, environmental influence and poor infrastructure in schools are the significant causes of examination cheating behaviors among consumers of post-primary education in Enugu, Nigeria.

To test hypothesis two, the responses to question 2I as contained in the questionnaire was used.

Tables 4 and 5 contain the descriptive statistics and t-test for the questions used to test the hypothesis.

Table 4: One-Sample Statistics

\begin{tabular}{lllll}
\hline & $\mathrm{N}$ & Mean & Std. Deviation & Std. Error Mean \\
\hline $\begin{array}{l}\text { The causes of examination } \\
\text { cheating behaviors }\end{array}$ & 5 & 46.4000 & 31.80880 & I4.22533 \\
\hline Source: Data Analysis & & & & \\
\hline
\end{tabular}

Table 5: One-Sample Test

\begin{tabular}{|c|c|c|c|c|c|c|}
\hline & \multicolumn{6}{|c|}{ Test Value $=0$} \\
\hline & \multirow[b]{2}{*}{$\mathrm{T}$} & \multirow[b]{2}{*}{ Df } & \multirow[b]{2}{*}{ Sig. (2-tailed) } & \multirow[b]{2}{*}{$\begin{array}{l}\text { Mean } \\
\text { Difference }\end{array}$} & \multicolumn{2}{|c|}{$\begin{array}{l}95 \% \text { Confidence Interval of the } \\
\text { Difference }\end{array}$} \\
\hline & & & & & Lower & Upper \\
\hline $\begin{array}{l}\text { The causes of examination } \\
\text { cheating behaviors }\end{array}$ & 3.262 & 4 & $.03 \mathrm{I}$ & 46.40000 & 6.9042 & 85.8958 \\
\hline
\end{tabular}

As shown in table 5, the t-test resulted in a t-value of 3.262 and $\mathrm{P}$ - value of $0.03 \mathrm{I}$ which is less than 0.05 . Following this, therefore the null hypothesis which states that inadequate preparation, environmental influence and poor infrastructure in schools are not the significant causes of examination cheating behaviors among consumers of post-primary education in Enugu, Nigeria $\left(t_{c a l}=3.262, \mathrm{P}=0.03 \mathrm{I}<0.05\right)$ is rejected. The alternate hypothesis which states that inadequate preparation, environmental influence and poor infrastructure in schools are the significant causes of examination cheating behaviors among consumers of post-primary education in Enugu, Nigeria is accepted. 
This finding is in agreement with the findings of some other researchers including Badmus (2006), Nwandiani (2005), Okafor (2006), Ayua (2006), Ivowi (1997). Ivowi (1997) notes that lack of confidence as a result of inadequate preparation, peer influence, societal influence parental support (environmental influences) as well as inadequate facilities in schools are some of the factors responsible for examination cheating behaviors.

\section{Conclusion, Implications and Recommendations}

In line with the findings of this study, it can be concluded that the gender of consumers of post-primary education has an insignificant influence on the incidence of examination cheating behaviors in post-primary schools in Enugu, Nigeria. Male consumers of educational services have a higher tendency of engaging in examination cheating behaviors than female consumers of educational services in Enugu, Nigeria. Also, examination cheating behaviors among consumers of educational services in Enugu, Nigeria are caused by a combination of personal attributes of the consumers and group/ societal influences.

In essence, all post-primary schools in Enugu, Nigeria are prone to examination cheating behaviors, irrespective of the gender composition of the schools. Likewise, consumers (students) alone are not to blame for the occurrence of examination cheating behaviors in post-primary schools in Enugu, Nigeria because the environment, quality of staff and facilities are also contributory factors.

More effort should be intensified to fight the menace of examination cheating behaviors in post-primary schools in Enugu, Nigeria. There is a need for proper orientation and sensitization of all concerned, especially students, teachers and examiners on the need to curb this menace. It is also necessary to improve the quality of facilities and the teaching staff in postprimary schools before the incidence of examination malpractices can be curtailed.

A conscious effort should be made to see that students are well prepared for examinations before sitting for these examinations. This will go a long way to reduce the effect of inadequate preparation on the incidence of examination cheating behaviors. Generally, all schools should be monitored, irrespective of their gender compositions, to check the rate of occurrence of examination cheating behaviors in these schools.

\section{References}

Adeyemi, T. O. (2010). Examination Malpractices Among Secondary School Students in Ondo State, Nigeria: Perceived Causes and Possible Solutions. Journal of Educational Administration and Policy Studies, 2 (3), 48-55.

Aghenta, J.A. (2000). Educational Planning in the 2It Century in Educational Planning and Administration in Nigeria in the 2 It $^{\text {st }}$ Century, J.O. Fadipe \& E.E. Oluchukwu (eds.) A Publication of the National Institute for Educational Planning and Administration (NIEPA).

Aminu, J. (2006). Examination Malpractice in Nigeria: Roots, Sustenance, Endemicity, Dangers and Assailant. Keynote Address Delivered in a Two-Day Summit on Examination Malpractice in Nigeria Organized by the House of Representatives Committee on Education Held at the Shehu Musa Yar' Adua Centre, Abuja, August I5-I6.

Athanasou, J.A, \& Olasehinde, O. (2002). Male and Female Differences in Self-report Cheating. Practical Assessment, Research \& Evaluation, 8 (5). URL:Http://PAREonline.net/getvn.asp? $=8 \& \mathrm{n}=5$.

Ayua, I. A. (2006). Confronting Legal Issues in Examination Malpractice: the Law, Prosecution and Judicial Processes. Speech Delivered at a Two-Day Summit on Examination Malpractice in Nigeria Organized by the House of Representatives Committee on Education Held at the Shehu Musa Yar' Adua Centre, Abuja, August I5-I6.

Azare, G. D. (2006) Accountability in Teaching \Learning Environment and Examination Malpractices. A Paper Presented at a Two-Day Summit on Examination Malpractice in Nigeria Organized by the House of Representatives Committee on Education Held at the Shehu Musa Yar' Adua Centre, Abuja, August I5-I6.

Badejo, A. O. \& Gandonu, M.B. (2010). Predisposing Factors Towards Examination Malpractice Among Students in Lagos Universities: Implications for Counseling. Edo Journal of Counseling, 3(2), 197-209.

Badmus, G. A. (2006). Accountability in Teaching \Learning Environment and Examination Malpractices. A Paper Presented at a Two-Day Summit on Examination Malpractice in Nigeria Organized by the House of Representatives Committee on Education Held at the Shehu Musa Yar' Adua Centre, Abuja, August I5-I6.

Bandura, A. (I99Ia). Social Cognitive Theory of Self-Regulation. Organizational Behaviour and Human Decision Processes, $50,248-287$.

Bandura, A. (I99Ib). Social Cognitive Theory of Moral Thought and Action. In W.M. Kurtines \& J. L. Gewirtz (Eds.), Handbook of Moral Behaviour and Development, I, 45-I03 Hillsdale, NJ: Erlbaum.

Berger, P.D., Bolton, R.N., Bowman, D., Briggs, E., Kumar, V., Parasuraman, A., \& Terry, C. (2002). Marketing actions and the value of customer assets: A framework for customer asset management. Journal of Service Research, 5 (I),39-54.

Bowers, W. J. (1984). Student Dishonesty and its Control in College. Bureau of Applied Social Research, Colombia University, New York.

Bruno, U.D.O. \& Obidigbo, G.C.E (2012). The Counseling Implications of Examination Malpractice Among University Undergraduates. Research Journal in Organizational Psychology and Educational Studies, I (3), 199-202. 
Centre for Academic Integrity. (2005). C.A.I. URL:Http://www.academicintegrity.org

Cornelius-Ukpepi, B.U., Ndifon, R.A. \& Enukoha, O.I. (2012). Correlates of Examination Malpractice and Academic Performance of Primary School Students in Cross River State, Nigeria. American Journal of Social Issues and Humanities, 2(6), 398-405.

Craven, D. W., \& Piercy, N.F. (2013). Strategic Marketing, 10 ${ }^{\text {th }}$ edition. New York: McGraw-Hill,

Cromwell S. (2000). What Can We Do To Curb Students' Cheating? Education World. URL:Http://www.educationworld.com/a_admin/adminI44.shtml.

FGN (2004). National Policy on Education, Lagos, Federal Ministry of Education, 7: 20-29.

Federal Republic of Nigeria (1999). Examination Malpractice Act. Lagos: Government Press.

Gibbs, J.P. (1975). Crime, Punishment and Deterrence, Amsterdam: Elsevier.

Good, T. L., Nichols, S. L., \& Sabers, D. L. (1999). Understanding Youths Commitment to Schools and Toward a more differentiated View. Social Psychology of Education, 3, I-39.

Gottfredson, M.R. \& Hirschi, T. (I990). A General Theory of Crime, Stanford: Stanford University Press.

Gross J. (2003). Exposing the Cheat Sheet, with the Students' Aid. The New York Times, November 26, 2003.URL: http://www.eci-whoswho.com/highschool/anualsurveys/29.shtm.

Glasner J. (2002). Where Cheaters Often Prosper. Wired News. August 26, 2002 (Retrieved online November I9, 2002, Retrieved from http://www.wired.com/news/school/0,I383,5457I,00htm.

Hill, K. T. (1972). Anxiety in the Evaluative Content. In W. Hartrup (Ed.), The Young Child, (Vol.2: 37-40). Washington, D.C: National Association for the Education of the Young Children.

Hurwitz, N. \& Hurwitz, S. (2004). Words on Paper. American School Board Journal, I9I(3), I6-20.

Hyde, J.S. \& Linn, M.C. (I988). Gender Difference in Verbal Ability. A Meta-analysis. Psychological Bulletin, I04, 53-69.

Ige, J.A. (2002). Examination Malpractices in Schools, Paper Presented at the Senior Staff Seminar, Ministry of Education, Ekiti, Nigeria, March, 2-9.

Ivowi, U. M. 0. (1997). Examination Malpractices: Profile, Causes, Warning Signs, Case Studies, Prevention and Detection Strategies in Onyechere, I. (Ed.). Promoting Examination Ethics: the Challenges of a Collective Responsibility, Lagos: Potomac Books.

Jega, A. M. (2006). Examination Malpractice: Concept, Causes, Consequences and Remedies. Education for Today, 6(2), 5972.

Joshua, M. T. (2008a). Examination Malpractice: The Monster in Our Midst. Paper presented at Intervention Workshop for Teachers of English Language, Mathematics and Science Subjects in Akwa Ibom State, Nigeria, SeptemberNovember.

Joshua M. T. (2008b). Intervention Strategies in Curbing Examination Malpractice in Schools: The Role of Government and Teachers. Paper Presented at Stakeholders Forum on Examination Malpractice, Organized by Cross River State Ministry of Education, Calabar, Nigeria, December, I6.

Kleiner, C. (I999). The Cheating Game. US News and World Report 22. URL:Http://search.e[net.com.

Kotler, P., \& Armstrong, G. (20I4). Principles of marketing (I $5^{\text {th }}$ global edition). New Jersey: Pearson.

Kotler, P., \& Keller, K.L. (20I2). Marketing management (I4 ${ }^{\text {th }}$ ed.). London: Pearson Education Limited.

Murdock, T. B., Hale, N. M., \& Webber M. J. (200I). Predictors of Cheating among Early Adolescents: Academic and Social Motivations. Contemporary Educational Psychology, 26(I): 96-II5.

McCabe, D. L., \& Trevino L. K. (I993). Academic Dishonesty: Honour Codes and Other Contextual influence. Journal of Higher Education, 64, 522-538.

McCabe, D. L., \& Trevino L. K. (1999). Individual and Contextual Influences on Academic Dishonesty: A Multi-campus Investigation. Research in Higher Education, 38(3), 379-396.

Minnesota State University (2006). Academic Dishonesty Article. Retrieved URL:Http://www.musu.edu/cetl/teachingresources/articles/acae micdishonesty.html.

Newberger, E. H. (2003). The Men They Will Become: The Nature and Nurture of Male Character. URL:http://www.elinewberger.com.

Nsekpong, E. U. (1986). Factors that Affect Student's Tendency to Cheat in Examination. Unpublished M. Ed Thesis, University of Calabar.

Nwadiani, M. (2005). Curbing Examination Malpractice in the Nigerian Educational System. A lead Paper presented at the First Annual Conference of the Faculty of Education, Ambrose Alli University, Ekpoma, November I0-I2.

Obidigbo, G.C.E. (20II). The Connection Between-Exam Malpractice and Exam Anxiety, Paper Delivered to Enugu Psychological Consortium Forum, Held at Enugu, August, 17.

Obo, F.E. (2008). Education Stakeholders Attitudes Towards Examination Malpractice and Their Preferred Intervention Strategies in Cross River State Secondary School System, Nigeria. Ph.D. Dissertation, University of Calabar, Nigeria. 
Ogunwuyi, J.A. (2005). Strategies for Coping with Indiscipline in Secondary Schools, Paper Presented at the All Nigeria Conference of Principals of Secondary Schools (ANCCOPSS) at the Mandatory Continuing Professional Training Workshop at Osogbo, Osun State, Nigeria from March I5-I6:2-I2.

Okafor, F. C. (2006). Confronting Environmental Issues in Examination Malpractice: Societal and Professional Support. A Paper Presented at a Two-Day Summit on Examination Malpractice in Nigeria Organized by the House of Representatives Committee on Education Held at the Shehu Musa Yar' Adua Centre, Abuja, August I5-I6.

Olagboye, A.A.(2004). Introduction to Educational Management in Nigeria. Ibadan, Nigeria: Daily Graphics(Nig.) Limited.

Olatoye, R. A. (2006). Checking the Menace of Examination Malpractice in Nigeria. URL:Http://www.naere.org/journal/volums/nco.I.

Owuamanam, D.O (2005). Ethics and Professionalism in Academics. Paper Presented at the Faculty of Education Seminar, University of Ado-Ekiti, Nigeria on I6 ${ }^{\text {th }}$ May, 2-7.

Ossai, M.C. (20I I). Study Habit Predicts Examination Behaviour: An Imperative for Enhancing Quality of College Guidance and Counselling. Mediterranean Journal of Social Sciences, 2, 22-28.

Ravenscroft, S.P. \& Buckless, F.A. (I992). Cooperative Learning: Who Gains and Who Loses? Collected Abstracts of the American Accounting Association's Annual Meeting, August: I83.

Tang, S. \& Zuo, J.(1997). Profile of College Examination Cheaters. College Students' Journal, 3I(3), 340-437.

Tibbetts, S.G. (1997). Gender Differences in Students' Rational Decisions to Cheat. Deviant Behavior, I8(4): $393-4$ I4.

Vitro, F. J. (1972). The Effect of Probability of Test Success, Test Importance, and Risk of Detection on the Incidence of Cheating. Journal of Educational Psychology, IO(4), I88-194.

West African Examination Council (2000-2010). Annual Statistical Report of Examination Malpractice.

Whitley, B.E.(200I). Gender Differences in Affective Responses to Having Cheated: The Mediating Role of Attitudes. Ethics and Behaviour, II(3): 249-259.

Whitley, B. E., \& Keith-Spiegel, P. (2002). Academic Dishonesty: An Educator's Guide. Mahwah: Lawrence Erlbaum Publishers.

Appendix

Appendix I: Questionnaire

Instructions: Tick $(\sqrt{ })$ for the appropriate answer for each question

Section A: Personal Data

I. Are you a male or female?

2. What is your age bracket?

Yes []$\quad$ No

18-30

[ ] $\quad 30-40$

[ ] 4I-50[ ] Above 50 [ ]

3. What is your highest educational qualification? NCE/OND [ ] HND/B.Sc [ ]

4. What is your Marital Status? Single[ ] Married[ ] Divorced[ ] Widowed[ ]

5. What is your years of work experience?

$$
\begin{array}{ll}
\text { I - Less than five years } & {[\text { 5 years - less than I0 yrs }[\text { ] }} \\
\text { I0 yrs - less than I5yrs } & {[\quad] \quad \text { I5yrs and above } \quad[\text { ] }}
\end{array}
$$

\section{Section B:}

6. Are you a post-primary school teacher? Yes $[$ No $[$ ]

7. What is the gender composition of your secondary school?

$$
\text { Male only }[\quad] \quad \text { Female only }[\quad] \quad \text { Both Male and Female }[\text { ] }
$$

8. Which of these have you examined?

Internal examination only [ ] External examination only [ ] Both internal and external examinations 
9. Which of these is the most common type of examination cheating behavior among consumers of educational services in Enugu, Nigeria?

Impersonation [ ] 'Girraffing'/copying [ ] Bringing in foreign materials [ ] Changing of grades [ ] Leaking of examination papers [ ]

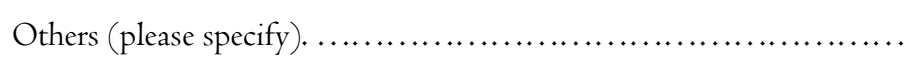

\section{Please indicate your level of agreement with the following statements (I0-I4)}

I0. Examination cheating behavior is a serious issue facing post-primary schools in Enugu, Nigeria.

$$
\text { Strongly Agree[ ] Agree[ ] Undecided[ ] Disagree[ ] Strongly Disagree[ ] }
$$

II. Examination cheating behaviours occur more in male post-primary schools than in female post-primary schools in Enugu, Nigeria.

$$
\text { Strongly Agree[ ] Agree[ ] Undecided [ ] Disagree[ ] Strongly Disagree[ ] }
$$

12. Gender composition of a post-primary school influences the level of examination cheating behaviours.

$$
\text { Strongly Agree[ ] Agree[ ] Undecided [ ] Disagree[ ] Strongly Disagree[ ] }
$$

13. Inadequate preparation, environmental influence and poor infrastructure in schools are the major causes of examination cheating behaviors in post-primary schools in Enugu, Nigeria.

$$
\text { Strongly Agree[ ] Agree[ ] Undecided[ ] Disagree[ ] Strongly Disagree[ ] }
$$

\section{Appendix II: Demographic Data of Respondents and Responses to Questions in Questionnaire}

Gender Distribution of Respondents

\begin{tabular}{llllll}
\hline & & & & Cumulative Percent \\
& Frequency & Percent & Valid Percent & \\
\hline Valid & Male & 64 & 27.6 & 27.6 & 27.6 \\
& Female & I68 & 72.4 & 72.4 & 100.0 \\
& Total & 232 & 100.0 & 100.0 & \\
\hline
\end{tabular}

Source: Field Survey

Age Distribution of Respondents

\begin{tabular}{llllll}
\hline & & & & Cumulative Percent \\
\hline Valid & Frequency & Percent & Valid Percent & \\
& I8-30 & 2 I & 9.1 & 9.1 & 9.1 \\
& 72 & 31.0 & 31.0 & 40.1 \\
& 4I-50 & 84 & 36.2 & 36.2 & 76.3 \\
& 50 And Above & 55 & 23.7 & 23.7 & 100.0 \\
& Total & 232 & I00.0 & I00.0 & \\
\hline
\end{tabular}

Source: Field Survey

Educational Qualifications of Respondents

\begin{tabular}{llllll}
\hline & & Frequency & Percent & Valid Percent & Cumulative Percent \\
\hline Valid & HND/Bachelor & I85 & 79.7 & 79.7 & 79.7 \\
& Masters & 47 & 20.3 & 20.3 & 100.0 \\
NCE/OND & 0 & .0 & .0 & 100.0 \\
Ph.D & 0 & .0 & .0 & 100.0 \\
Total & 232 & I00.0 & I00.0 & \\
\hline
\end{tabular}

Source: Field Survey 
Marital Status of Respondents

\begin{tabular}{llllll}
\hline & & Frequency & Percent & Valid Percent & Cumulative Percent \\
\hline Valid & Divorced & 8 & 3.4 & 3.4 & 3.4 \\
& Married & I24 & 53.4 & 53.4 & 56.8 \\
& Single & 68 & 29.3 & 29.3 & 86.1 \\
& Widowed & 32 & 13.9 & 13.9 & 100.0 \\
& Total & 232 & 100.0 & 100.0 & \\
\hline
\end{tabular}

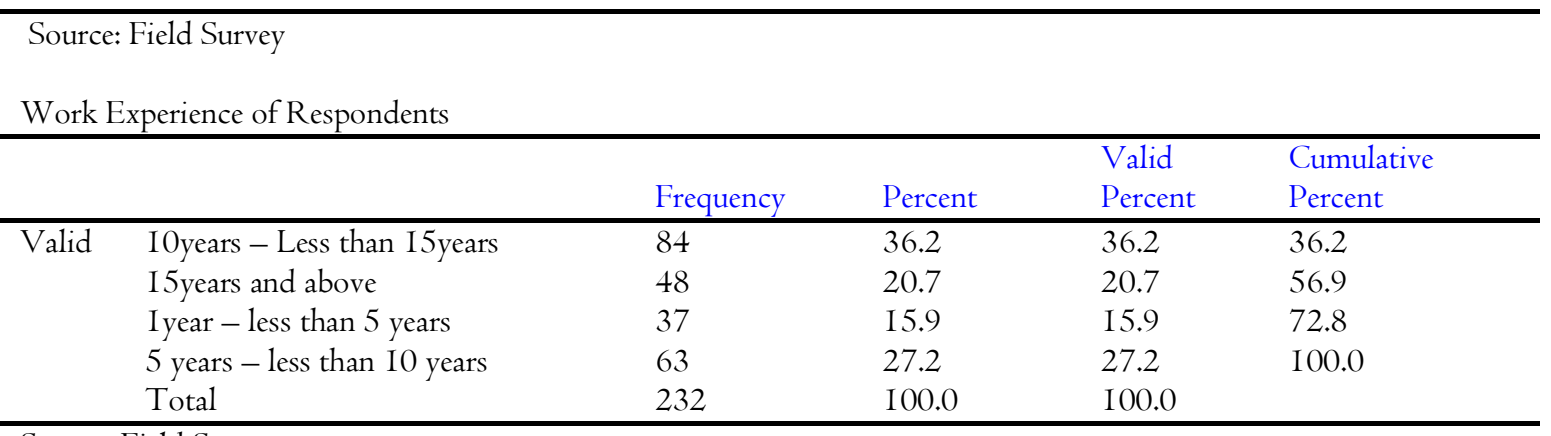

Source: Field Survey

Whether Respondent is a Post-primary School Teacher

\begin{tabular}{llllll}
\hline & & & & Cumulative Percent \\
& & Frequency & Percent & Valid Percent & \\
\hline Valid & Yes & 232 & 100.0 & 100.0 & 100.0 \\
& No & 0.0 & 0.0 & 0.0 & 100.0 \\
& Total & 232 & 100.0 & 100.0 & \\
\hline
\end{tabular}

Source: Field Survey

Gender Composition of School

\begin{tabular}{llllll}
\hline & & & Valid & Cumulative Percent \\
& & Frequency & Percent & Percent & \\
\hline Valid & Both Male and Female & 44 & 20.0 & 20.0 & 20.0 \\
& Female only & 103 & 44.4 & 44.4 & 64.4 \\
& Male only & 85 & 36.6 & 36.6 & 100.0 \\
& Total & 232 & 100.0 & 100.0 & \\
\hline
\end{tabular}

Source: Field Survey

Type of Examination Respondent Has Examined

\begin{tabular}{llllll}
\hline & & & Valid & $\begin{array}{l}\text { Cumulative } \\
\text { Percent }\end{array}$ \\
\hline Valid & Both Internal and External & Frequency & Percent & Percent & 94.4 \\
& External Examination only & 2I9 & 94.4 & 94.4 & 94.4 \\
& Internal Examination only & I3 & 0.0 & 0.0 & 100.0 \\
& Total & 232 & 5.6 & 5.6 & \\
\hline
\end{tabular}

Source: Field Survey 
Most Common Type of Examination Cheating Behavior.

\begin{tabular}{|c|c|c|c|c|c|}
\hline & & Frequency & Percent & $\begin{array}{l}\text { Valid } \\
\text { Percent }\end{array}$ & $\begin{array}{l}\text { Cumulative } \\
\text { Percent }\end{array}$ \\
\hline \multirow[t]{7}{*}{ Valid } & Bringing in foreign materials & 3 & 1.3 & 1.3 & 1.3 \\
\hline & Changing of Grades & $\mathrm{I}$ & 0.4 & 0.4 & I.7 \\
\hline & 'Girraffing'/Copying & 207 & 89.2 & 89.2 & 90.9 \\
\hline & Impersonation & $2 \mathrm{I}$ & 9.1 & 9.1 & 100.0 \\
\hline & Leaking of Exam papers & 0 & 0.0 & 0.0 & 100.0 \\
\hline & Others & 0 & 0.0 & 0.0 & 100.0 \\
\hline & Total & 232 & 100.0 & 100.0 & \\
\hline
\end{tabular}

Source: Field Survey

Examination Cheating Behaviour is a Serious Issue Facing Post-primary Schools in Enugu, Nigeria.

\begin{tabular}{llllll}
\hline & & & & Cumulative \\
Valid & Strongly Agree & 99 & Percent & Valid Percent & 42.7 \\
& Agree & 124 & 42.7 & 42.7 & 96.1 \\
& Undecided & 7 & 53.4 & 53.4 & 99.1 \\
& Disagree & 2 & 3.0 & 3.0 & 100.0 \\
& Strongly Disagree & 0 & 0.9 & 0.9 & 100.0 \\
& Total & 232 & 0.0 & 0.0 & \\
\hline
\end{tabular}

Source: Field Survey

Examination Cheating Behaviours Occur More in Male Post-primary Schools than in Female Post-primary Schools.

\begin{tabular}{llllll}
\hline & & & & Cumulative \\
Valid & Strongly Agree & 67 & Percent & Valid Percent & Percent \\
& Agree & I24 & 28.9 & 28.9 & 28.9 \\
& Undecided & 53.5 & 53.5 & 82.4 \\
& Disagree & I3 & 5.6 & 5.6 & 88.0 \\
Strongly Disagree & I I & 4.7 & 4.7 & 92.7 \\
Total & I & 7.3 & 7.3 & 100.0 \\
\hline
\end{tabular}

Source: Field Survey

Gender Composition of a Post-primary School Influences the Level of Examination Cheating Behaviours

\begin{tabular}{|c|c|c|c|c|c|}
\hline & & Frequency & Percent & Valid Percent & $\begin{array}{l}\text { Cumulative } \\
\text { Percent }\end{array}$ \\
\hline \multirow[t]{6}{*}{ Valid } & Strongly Agree & 73 & 31.5 & 31.5 & 31.5 \\
\hline & Agree & $\mathrm{I} 2 \mathrm{I}$ & 52.2 & 52.2 & 83.7 \\
\hline & Undecided & II & 4.7 & 4.7 & 88.4 \\
\hline & Disagree & $\mathrm{I3}$ & 5.6 & 5.6 & 94.0 \\
\hline & Strongly Disagree & $\mathrm{I} 4$ & 6.0 & 6.0 & I00.0 \\
\hline & Total & 232 & I00.0 & 100.0 & \\
\hline
\end{tabular}

\begin{tabular}{|c|c|c|c|c|c|}
\hline \multicolumn{6}{|c|}{ Source: Field Survey } \\
\hline & & Frequency & Percent & Valid Percent & $\begin{array}{l}\text { Cumulative } \\
\text { Percent }\end{array}$ \\
\hline \multirow[t]{6}{*}{ Valid } & Strongly Agree & 89 & 38.4 & 38.4 & 38.4 \\
\hline & Agree & 107 & 46.1 & 46.1 & 84.5 \\
\hline & Undecided & 13 & 5.6 & 5.6 & 90.1 \\
\hline & Disagree & $\mathrm{I} 5$ & 6.5 & 6.5 & 96.6 \\
\hline & Strongly Disagree & 8 & 3.4 & 3.4 & 100.0 \\
\hline & Total & 232 & 100.0 & 100.0 & \\
\hline
\end{tabular}

Source: Field Survey 
Inadequate Preparation, Environmental Influence and Poor Infrastructure in Schools are the Major Causes of Examination Cheating Behaviours in Post-primary Schools in Enugu, Nigeria.

\begin{tabular}{|c|c|c|c|c|c|}
\hline & & Frequency & Percent & Valid Percent & $\begin{array}{l}\text { Cumulative } \\
\text { Percent }\end{array}$ \\
\hline \multirow[t]{6}{*}{$\overline{\text { Valid }}$} & Strongly Agree & 79 & $34 . \mathrm{I}$ & $34 . \mathrm{I}$ & 34.1 \\
\hline & Agree & 83 & 35.8 & 35.8 & 69.9 \\
\hline & Undecided & 21 & 9.1 & $9 . \mathrm{I}$ & 79.0 \\
\hline & Disagree & 29 & $\mathrm{I} 2.5$ & $\mathrm{I} 2.5$ & 91.5 \\
\hline & Strongly Disagree & 20 & 8.5 & 8.5 & 100.0 \\
\hline & Total & 232 & 100.0 & 100.0 & \\
\hline
\end{tabular}

Source: Field Survey

\section{Copyrights}

Copyright for this article is retained by the author(s), with first publication rights granted to the journal. This is an open-access article distributed under the terms and conditions of the Creative Commons Attribution license (http://creativecommons.org/licenses/by/4.0/). 